\title{
Conversando com Vilma Arêas
}

Antonio Arnoni Prado

Acho que no prefácio do seu livro Partidas (1976) há uma boa pista do tipo de trabalho que você faz com a linguagem. Nele você usa como entrada a cópia de uma fatura encontrada na Torre do Tombo, com a qual um mestre de obras detalhou, em 1853, a lista de consertos e despesas necessárias à restauração do retábulo da Capela do Bom Jesus de Braga. Ali, de um modo tosco e seco, como exigia a sua tarefa, o homem vai desfigurando sem qualquer cerimônia o espaço sagrado de alguns símbolos indevassáveis da liturgia: "corrigir os dez mandamentos, embelezar o Sumo Sacerdote e mudar-lhe as fitas (170 réis); dourar e pôr penas na asa esquerda do Anjo da Guarda (120 réis); avivar as chamas do inferno, pôr um rabo novo a um diabo e pôr uns cornos ao diabo mais velho (370 réis); retocar o purgatório e pôr-lhe almas novas (335 réis); compor o fato e a cabeleira de Herodes (30 réis); compor a burrica do filho pródigo (23 réis) e pregar uma estrela que caiu ao pé do coro (23 réis)", e assim por diante.

Essa é uma atitude que está na escritora, mas também na ensaísta, que desarticula os diálogos de amor pela graça de verdade que os pressupõe e valoriza como dado novo de sensibilidade e de reflexão. Num conto como "Arrolamento" (Partidas), por exemplo, numa atmosfera em que o amor tanto mais atrai quanto mais se manifesta o desamor, o que equilibra o texto é o achado de uma afeição corrosiva que faz os amantes se amarem e desamarem simultaneamente, numa espécie de pré-requisito sine qua non:

\footnotetext{
- Viverias sem mim? (diz ele) - Claro. - Claro o quê?... - Que viveria sem você...(ela responde)

- Vou-me embora (ele acrescenta). - Acho perfeitamente natural (ela responde). - Natural o

quê?... (ele insiste) - Que te vás embora (ela explica). - E se eu ficar?... - Podes ficar (conclui).
}

nhão.

E ainda: - Como te chamas? - Mercedes. - Que gozo! - Gozo por quê? - Nome de cami-

Como registra um conto anterior, para o narrador (quase sempre) não há propriamente uma situação errada, situações certas são o vaz̧io admitido entre duas situações erradas. Situações certas existem por hipótese, para que se entendam as situações erradas... para que existam situaçôes... Mas isso não é tudo, o melhor vem depois. É que para o narrador dos seus contos é insuportável a idéia de que o homem foi feito para ficar tranqüilo na pupila do observador. A todo momento, nós o vemos cuspir esta necessidade, altivo, endurecido apesar de sempre amarrado ao desespero do outro. Ele mesmo se confessa: como fazer sem o teu desespero dentro de minha completa indiferença?.

O melhor exemplo é o da repetição da cena "Adocicada memória" em que a personagem, antes de partir, berra no cais do porto: Viva Portugal. Na primeira imagem, onde é descrita como uma mulher amada, o grito heróico satisfaz o orgulho dos amigos que ficavam: Assim é que se parte de um país que perdemos. Na segunda cena, onde não desfruta do amor dos outros, ela apenas grita um Viva Portugal muito honesto, e todos os 
amigos dão adeus do cais fingindo que não estavam sentidos demais para não exibirem atitudes antiquadas... . Entre as duas cenas vale o comentário envenenado que recusa a emoção : a esquizofrenia é apenas um problema quimico, que se completa (na primeira) com uma rubrica que define um princípio de composição. Diz o narrador: se ela chorasse, a lágrima circunspecta seguiria o sulco da carne aberta, o caminho macio forrado de creme Nivea, porque faz, pena uma lágrima rolar muito tonta num rosto liso. A segunda cena, dispensa o comentário, porque aqui o que muda é a própria personagem: destituída do afeto, uma outra descrição vem anular a primeira. Agora, ela é só uma mulher com dois pequenos peitos e um nariz fino como uma gilete, e tem todo o vigor de um retrato realista, mas não cabe no arranjo da elocução que o seu relato admite. Nele as coisas jamais se harmonizam: iguaizinhos entre si, só os lados de um quadrado - mas não se pode esquecer que a geometria é uma abstração - ele explica.

Qual é saída? Parece que não existe. Num texto de $A$ terceira perna o narrador declara que o único fato a constatar é que fugimos das cores vulgares da realidade contemporânea e obtemos de chofre, como numa festa de grande gala, a elegância absoluta do desespero, que também se chama humor. Neste ponto é que compreendemos que a irradiação da historia é treva, porque mesmo nos gestos mais fortuitos ou mais neutros, persiste algo de duro, de inadmissivel. E a crueldade emerge da nudez, assim que o fascínio é abalado.

E essa é uma constatação de rotina. Entra mesmo num livro para crianças, onde a menina (a narradora) diz ter uns sonhos bem debilóides (os termos são dela) e num deles se imagina - como é natural - descendo de saia comprida uma baita escadaria com tapete vermelho, tão bonita que ela tem até medo de acordar. Mas tem que ser sempre escadaria bem alta, para subir e descer com pompa. Elevador por exemplo não serve. Não é a mesma coisa, - ela explica - não tem o mesmo charme. Você aperta um botão, lá vem ele, é um saco. Essa atmosfera invade o universo infantil e se expande de modo exemplar num texto como "O homem louco", que Teo, um garoto, lê calmamente para Chico, outro garoto:

O homem louco acorda de manhã, toma café e vai pro trabalho. Chega lá, conversa com seus amigos e depois trabalha. Depois do trabalho toma uma bebidinha, conversa mais um pouco com os amigos e volta pra casa. Depois descansa e assim vive feliz. Esta é a história do homem louco.

Levada para o mundo dos adultos, essa argúcia pelo banal, que aniquila as coisas, transforma o menino do conto "Boi boiada" num demônio para o pobre pai que não sabe onde pôr o juízo diante de tantas questões de ordem poética: para onde é que vão as coisas quando anoitece, onde é que as coisas dormem? E se quebrasse a rua? É como se quebrasse o cinema? E de noite, como é que o rio dorme, o menino assombrado: o rio então fica por aí, de noite, não dorme, será?.

Essas considerações não pretendem ser uma análise da sua ficção, Vilma. Eu só quis falar desses aspectos porque o regulamento me exige algum comentário sobre o seu Memorial. Claro que daria para aprofundar, e muito, a situação do narrador nos seus textos. Falar, por exemplo, do quanto você se vale da literatura e das outras artes para contextualizar o beco sem saída onde estão metidos os seus personagens (com exceção talvez dos de Trouxa frouxa). Graciliano Ramos, Mario Quintana, Borges ... aparecem 
como lenitivos de expressão fugaz, mas fundante, que preservam o peso da aura e assim tornam o impasse um pouco mais palatável.

Mas o valor do seu Memorial está, a meu ver, na contraparte dessa dimensão ensaística da sua prosa. Ele nos mostra, por exemplo, em primeiro lugar, o peso do ficcional (quer dizer também: do circunstancial) no seu percurso acadêmico, coisa que a todo tempo interfere na articulação do saber específico do professor de Letras desde o começo. A idéia de estudar literatura não se separa da idéia de escrever ficção, mas a professora de literatura que consegue uma bolsa do Conselho Britânico e vai para a Inglaterra aperfeiçoar os conhecimentos de fonética e literatura inglesa moderna, quando volta, desiste de tudo, por não ver mais sentido em ensinar língua estrangeira a alunos do curso noturno de um ginásio pobre da periferia de Niterói, que desmaiavam de fome na sala de aula e sequer conseguiam comprar os livros. O relato singulariza o episódio e, numa peça curricular de caráter acadêmico-retórico (como é o Memorial), em que o normal é acumular de referências, notas, apêndices, codicilos, diplomas e prêmios enobrecedores para o candidato e a Instituição - no seu caso se reduz a uma curta fala do médico do posto de saúde do bairro, dizendo: travessão, abre aspas : "Dá um copo de leite. Está com fome", e o aluno ficava bom e voltava para casa.

Isso levou você a trocar a literatura inglesa pelo ensino da língua e da literatura brasileira e portuguesa, mas agora num colégio mais distante, em Matadouro, zona operária e última estação de trem da Central do Brasil, onde a principal atividade era desenvolver o discernimento dos estudantes, tentando integrá-los à realidade social que os envolvia. Claro que interessava a literatura, mas interessava talvez mais do que ela naquele momento - o texto dos jornais em classe "para que eles tomassem conhecimento do que estava acontecendo no país naqueles anos", quando os professores eram fiscalizados e havia inclusive microfones ligando as classes ao gabinete da Direção. Não vou traçar aqui todo o percurso, mas apenas assinalar como aí se define uma atitude intelectual que, por assim dizer, define a Vilma que nós conhecemos hoje, e que passa:

1) pela ida a Portugal, por indicação do prof. Thiers Martins Moreira, e o interesse pela novela atribuída a Antonio José da Silva, Obras do diabinho da mão furada, onde a intenção era observar como a ficção driblava a opressão, ou, no caso, como o diabinho fulminava embelecos, ou seja: (cito palavras suas) as artimanhas do autor para driblar a Inquisição, construindo uma espécie de registro sonso que negaceava com a compreensão direta, sob a capa de pretensa ingenuidade;

2) pela tentativa de uma edição crítica de $S$. Bernardo, de Graciliano Ramos, sendo já professora, mas aguardando contrato da Universidade Federal do Rio de Janeiro, de onde seria expulsa em nome de princípios também ditos democráticos;

3) pelo contato e a militância política com os colegas da PUC do Rio nos anos de 1970, onde apresentou um mestrado (A cicatriz e o verbo) sobre as inovações do neorealismo no âmbito da literatura de vocação política, com foco na prosa de Augusto Abelaira;

4) pelas relações com a literatura africana de expressão portuguesa, num curso que acabou não indo adiante, mas que rendeu frutos de pesquisa junto aos alunos, em 
sinal de desobediência às ordens irracionais, com um ganho considerável: a formação de uma colega hoje docente dessa disciplina na USP. Outra experiência interessante nessa etapa foi, por exemplo, a leitura ideológica e a discussão, em forma de poesia, do "Vou-me embora pra Pasárgada", de Manuel Bandeira, feita pelos poetas da guerrilha;

5) pela transferência para São Paulo, em razão de duras conseqüências pessoais, que trouxe o convívio com a obra de Martins Pena, a experiência na USP e em seguida a vinda para a Unicamp, ao longo da qual poderíamos ficar aqui falando horas, se pensarmos nos artigos, ensaios, conferências, textos para congressos e livros de ficção. O destaque, aqui, fica para o ensaio original $A$ tapera de Santa Cruz, onde você nos mostra um Martins Pena crítico e autor, no corpo a corpo com a censura e as limitações sociais e culturais do teatro de seu tempo, mas sobretudo o teatrólogo que deixa a ingenuidade de simples comediógrafo de periferia para, primeiro, propor uma solução brasileira para a arte, alinhando-se a Machado de Assis e a Mario de Andrade, a partir das constatações de Roberto Schwarz e Gilda de Mello e Souza, que você aproveita e harmoniza; e, depois, pela introdução do peso dissonante do escravo no argumento de suas comédias.

Apenas para dar uma idéia, é preciso dizer que a ficção sempre continuou e a ojeriza pelas tarefas administrativas também, o que a meu ver encorpa a noção de coerência já implícita na atitude crítica que se veio definindo. Quanto aos muitos aspectos da sua contribuição acadêmica nessa etapa, bastaria lembrar, para encerrar, o interesse por aquele que você define como o lado menor de Clarice Lispector, o lado próximo da paródia, da comicidade, do grotesco e suas máscaras, em estudos que você mesma discute e relativiza enquanto estratégia, vendo neles excessos e buracos, mas com conquistas e realizações admiráveis, como o revela, por exemplo, o número especial da Remate de Males dedicado à Autora, de cuja organização você participou.

Mas há também a importante pesquisa sobre narrativa contemporânea, presente em seus cursos e estudos esparsos, como o belo ensaio sobre a prosa de Modesto Carone, que passa pelas reflexões sobre o feminino em Luzia Homem, de Domingos Olímpio, sobre a prosa de Campos de Carvalho, sobre os contos de Gilda de Mello e Souza, sobre a obra de Rachel de Queiroz, da própria Clarice Lispector, de Graciliano Ramos, de Rodrigo Naves, de João Inácio Padilha, de Jean Claude Bernardet, de João Almino, de Paulo Lins, de Zulmira Ribeiro Tavares, sem esquecer o interesse pela poesia que desmancha em prosa, ou que subsiste de forma dissimulada. Diz você que é essa dissimulação que me interessa investigar, numa fiç̧ão esperta e experiente quanto a matrizes narrativas, mas que como desde o inicio - não se furta a correr riscos.

O que chama atenção é que esse estudo da ficção contemporânea vem como um reflexo do seu próprio projeto literário, sempre discutido e rediscutido com os amigos, levando o grande peso da sua experiência para o outro, fazendo-se a partir do outro e centrada sobretudo no outro.

Mas o melhor de tudo isso, Vilma, foi poder ter convivido com você, aqui no IEL, todos esses anos, em cada encontro uma alegria, um desabafo, uma incerteza - uma coisa viva e humana, verdadeiro desarranjo que alimenta o inconformismo e nos ajuda a compreender a literatura, quase sempre tão distante da sisudez burocrática do ambiente que 
você, a seu modo, sempre soube despistar e mudar de sentido, como um caminho sempre novo a nossa frente.

Notas

$1 \mathrm{O}$ autor fez parte da banca de concurso de Vilma Arêas para professora titular do Departamento de Teoria Literária do Instituto de Estudos da Linguagem da Universidade Estadual de Campinas em 2002.

O texto aqui publicado, com pequenas modificações, foi lido em uma das sessões do concurso. (NE) 